\title{
Introduction to an Occupational Perspective of Health
}

\author{
Hagyun Kim* \\ School of Social Work, Massey University, New Zealand
}

Submission: July 30, 2020; Published: August 24, 2020

*Corresponding author: Hagyun Kim, School of Social Work, Massey University, New Zealand

Keywords: Everyday activity; Health; Occupational science; Health conditions

\section{Opinion}

By shifting away from the bio-medical perspective, health is now widely recognised to relate to how people achieve a productive and fulfilling life regardless of their health conditions [1]. According to the WHO [2], health is created within the settings of people's everyday lives. That is, being healthy requires participation in activities of daily living that are part of one's sociocultural context. This indicates that health closely relates to having capacity in various types of daily activities which provide a sense of reality and achievement. The Ottawa Charter for Health Promotion supports this concept by identifying engagement in everyday activities as the prerequisites of health [3].

Given that health is determined by participation, which is embedded in everyday activities, this concept of health is closely connected to 'Occupational science' grounded in the notion that people engage in everyday activities for their existence and that the drive to be occupied has evolutionary, psychological, social, and symbolic roots [4]. It is a young science which was introduced in the latter decades of the $20^{\text {th }}$ century, to study the complicated relationships between 'people' and 'what they do'. A key feature of this scientific perspective is to examine the form, function and meaning of everyday activities in people's lives. In this sense, an occupational perspective of health highlights the connections between health and participation in everyday activities [4].

As noted above, 'everyday activities' are a central concept in occupational science. It is not narrowly confined to 'employment'; rather it encompasses "the stuff of everyday life" [5]. From an occupational perspective, everyday activities embrace all of the activities with which people perform to carry out their daily lives over the course of a day, week, month, year or life. These include 'eating', 'dressing, 'making a cup of tea', or even 'driving', and incorporate physical, social, psychological, emotional, and spiritual dimensions. Through those activities, people fill time, create the circumstances of everyday existence, interpret and comprehend the world, and express themselves and make their place in the world. The perspective taken is to examine every activity in which people participate for survival and connect them to social and cultural environments.

In that context, everyday activities are commonly categorised as 'self-care', 'productivity' and 'leisure' [1]. 'Self-care' is all about maintenance, from personal care to community. Activities in selfcare involve any activities where the intention is to stay physically and mentally fit. 'Productivity' is associated with activities with which people support self/family/society through the production of goods and services. Activities in this area relate to perceptions of self. 'Leisure' is characterised as a measurable residue of time and provides a suspension of reality, leading to enjoyment, relaxation, self-expression, and an internal locus of control. Through participation in activities across these three domains, people interpret and comprehend the world, and make their place in the world [4]. This makes it clear that health is determined by people's having of choices, abilities, and opportunities in activities across these three areas of social setting over their lifespan.

Additionally, occupational science posits that a person's self (being and becoming) is largely shaped by their daily patterns of everyday activities [1]. People's sense of who they are and can become is articulated through their participation in activities which have personal, cultural, and spiritual value to the individual. People's everyday activities are the basis for how they feel about themselves and determine their relationships with others. Through a reflexive process in which they make choices about how to occupy their time, people give life meaning and forge the self. In this sense, the self is constructed by participation in 
everyday activities; that is, life's meaning, a person's being, and everyday activities are inseparable [6].

Since it was founded in the 1980s, occupational science is grounded in the belief that people are most true to their humanity when they engage in daily activities. In particular, this scientific perspective views that health is determined by involvement in life situations and refers to people's experiences of everyday activities as the primary resources for health [1]. Bringing an occupational perspective to health has the potential to assist health professions to listen closely to people's actual experiences of everyday activities and holds promise for insightful knowledge into the development of people's opportunities and resources for participation in health-building activities in health contexts [7]. .

\section{References}

1. Wilcock A A, Hocking C (2015) An occupational perspective of health ( $3^{\text {rd }}$ edn.). Thorofare, NJ: Slack.

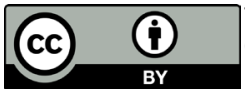

This work is licensed under Creative Commons Attribution 4.0 License

DOI: 10.19080/GJIDD.2020.06.555700
2. World Health Organization (2001) International classification of functioning, disability, and health; ICF. Geneva, Switzerland.

3. World Health Organization (1986) Ottawa Charter for health promotion. Geneva, Switzerland.

4. Yerxa E J (1990) An introduction to occupational science, a foundation for occupational therapy in the $21^{\text {st }}$ century. Occup Ther Health Care 6(4): 1-17.

5. Townsend E, Polatajko H (2007) Enabling occupation II: Advancing an occupational therapy vision for health, well-being \& justice through occupation ( $2^{\text {nd }}$ edn.). Ottawa: NJ.

6. Arola L A, Dellenborg L, Häggblom-Kronlöf G (2017) Occupational perspective of health among persons ageing in the context of migration. Journal of Occupational Science, 25(1): 65-75.

7. Therapy vision for health, well-being \& justice through occupation. CAOT publications. Ontario, Canada.

\section{Your next submission with Juniper Publishers will reach you the below assets}

- Quality Editorial service

- Swift Peer Review

- Reprints availability

- E-prints Service

- Manuscript Podcast for convenient understanding

- Global attainment for your research

- Manuscript accessibility in different formats

( Pdf, E-pub, Full Text, Audio)

- Unceasing customer service

Track the below URL for one-step submission https://juniperpublishers.com/online-submission.php 